Int. Archs Allergy appl. Immun. 1980;61:I-VI

\title{
Contents, Vol. 61, 1980
}

Vol. 61,1980

International Archives of Allergy and Applied Immunology

Founded 1950 by: D. Harley, P. Kallós, W. Löffler and F. W. Wittich

Continued by: E. A. Brown (1952-1954), W. Kaufman (1955-1967), F. Hahn (1961-1972) and

H. C. Goodman (1963-1975)

Editors-in-Chief:

R. R. A. Coombs, Cambridge L. M. Lichtenstein, Baltimore, Md.

Contributing Editors:

C. J. Abeyounis, Buffalo, N.Y. N. F. Adkinson, Jr., Baltimore, Md. G. Andres, Buffalo, N.Y. E.

L. Becker, Farmington, Conn. W. E. Brocklehurst, Windlesham

A. Cerletti, Basel

C. G. Cochrane, La Jolla, Calif.

B. Diamant, Copenhagen

P. Dukor, Basel

L. Edebo, Linköping

W. P. Faulk, Charleston, S.C.

H. Fischer, Freiburg-Zähringen

P. G. H. Gell, Birmingham

H. Gewurz, Chicago, Ill.

I. Glazer, Tel Aviv

R. A. Good, New York, N.Y.

P. Kallós, Helsingborg F. Milgrom, Buffalo, N.Y.

F. Hahn, Wittnau

L. Å. Hanson, Göteborg

M. Hess, Bern

L. Hudson, Beckenham

H. Isliker, Lausanne

S. G. O. Johansson, Uppsala

E. A. Kabat, New York, N.Y.

K. Kano, Buffalo, N.Y.

W. Müller-Ruchholtz, Kiel

ö. Ouchterlony, Göteborg

Z. Ovary, New York, N.Y.

P. Perlmann, Stockholm

E. Pick, Tel Aviv

M. Plaut, Baltimore, Md.

R. E. Reisman, Buffalo, N.Y.

G. Riethmüller, München 
Z. Trnka, Basel G. B. West, Epsom

M. Roitt, London

K. Rother, Heidelberg

H. D. Schlumberger, Wuppertal

A. Sehon, Winnipeg

E. Sorkin, Davos-Platz

H. Storck, Zurich

A. Szentivanyi, Tampa, Fla.

T. B. Tomasi, Jr., Rochester, Minn.

O. Tönder, Bergen

G. Torrigiani, Geneve

J. L. Turk, London

E. R. Unanue, Boston, Mass.

B. H. Waksman,

New Haven, Conn.

A. L. de Week, Bern

G. Wick, Innsbruck

S, Karger $\cdot$ Basel $\cdot$ München $\cdot$ Paris $•$ London $\cdot$ New York $\cdot$ Sydney

W

All rights reserved.

No part of this publication may be translated into other languages, reproduced or utilized in any form or by any means, electronic or mechanical, including photocopying, recording, microcopying, or by any information storage and retrieval system, without permission in writing from the publisher.

S.KargerAG, P.O.Box,4009 Basel (Switzerland)

Printed in Switzerland by Buchdruckerei National-Zeitung + Basler Nachrichten AG, Basel

Contents Vol. 61,1980

No.l

Original Paper

Comparison between Surface Components from Human B and Chronic Lymphatic Leukaemia

Lymphocytes Isolated by Lentil Lectin

Banderet, E. and Despont, J.-P 1

Movement of Calcium Ions and Release of Histamine from Rat Mast Cells

Ranadive, N.S. and Dhanani, N

9

An Enzymatic-Isotopic Microassay for Measuring Allergic Release of Histamine from Blood and Mast Cells in vitro

Taylor, K.M.; Krilis, S., and Baldo, B.A 19

Asbestosis and Systemic Lupus Erythematosus

Bartsch, P.; Salmon, J., and Mahieu, P 28

The Prickly Lettuce Agglutinin. I. Isolation from Leaves of the Prickly Lettuce Plant (Lactuca scariole)

Yen, S.E.; Mansfield, J.M., and Wallace, J.H 32

Effects of Ascorbic Acid on Neutrophil Locomotion

Dallegri, F.; Lanzi, G., and Patrone, F 40

Time-Lapse Cinematography of the Capillary Tube Cell Migration Inhibition Test 


\section{Bray, M.A 46}

Immunochemistry of Salmonella O-Antigens. Specificity of Rabbit Antibodies against the OAntigen 2 Determinant Elicited by Whole Bacteria and 3-o-a-Paratopyranosyl-Z?-

Mannopyranosyl Conjugated to Bovine Serum Albumin

Jörbeck, H.; Svenson, S.B., and Lindberg, A.A 55

The Antigens of Pigeon Breeder's Disease. III. Immunologically Related Antigens of Pigeon

Dropping Extracts: PDE, 2 AandB

Fredericks, W.W. and Tebo, T.H 65

Interaction of Doxantrazole with Calcium Ions in Solvents of Intermediate Polarity. Possible

Effect of Ionization of the Drug

Spitzer, J.C 75

Early Rheumatoid-Like Joint Lesions in Rabbits Injected with Foreign Serum or Milk Proteins.

III. Influence of Concomitant IgE-like Antibodies and of the Breed of Rabbit

Oldham, G. and Coombs, R.R.A 81

Antigens in Penicillin Allergy. V. On the Relative Allergenic Potency of Antigens Carrying

Penicilloyl Determinants Derived from Azidocillin, Ampicillin and Benzylpenicillin

Ahlstedt, S.; Kristofferson, A., and Hall, E 91

Enumeration and Characterization of Bovine Blood, Spleen and Lymph Node Cells Containing Immunoglobulins

Rothlein, R.; Johnson, D.W., and Muscoplat, C.C 100

Short Communications

Levamisole and Leucocyte Migration into Sponge Exudates

Griffiths, G. and West, G.B 107

Seasonal Variation in Drug Action and Animal Responses in Models of Inflammation

Warne, P.J. and West, G.B Ill

Skin Reactions of Rats to Levamisole and Z > -Penicillamine

Ruenitz, P.C.; Sorenson, J.R.J., and West, G.B 114

IV

Contents

No. 2

Original Paper

Aggregate Anaphylaxis in the Monkey. Haematological and Histological Findings (with 1 color plate)

Smedegàrd, G.; Revenäs, B., and Saldeen, T 117

Essential and Nonessential Cooperative Signals in Lymphocyte Triggering in Solid Cultures

Kondracki, E 125

Antigenic Composition of a Vaccine Strain of Francisella tularensis

Holm, S.E.; Tärnvik, A., and Sandström, G 136

Effect of Aspirin on Complement in vivo

Voigtländer, V.; Hänsch, G.M., and Rother, U 145

Effect of Aspirin on the Complement System in vitro

Hänsch, G.M.; Voigtländer, V., and Rother, U 150

Increase of TG Lymphocytes in Human One-Way Mixed Lymphocyte Culture

Meroni, P.L.; Ciboddo, G.F.; Colombo, G; Rugarli, C, and Zanussi, C 159

Development of Delayed Hypersensitivity in Gnotobiotic Mice

Collins, F.M. and Carter, P.B 165 
Receptors for IgG Fc and Complement in the Mammalian Aorta

Kasukawa, R.; Okada, M., and Igari, S 175

Preparation of Antisera Specific for Guinea Pig B Cells

Ota, F.; Parker, D.; Dwyer, J.M., and Turk, J.L. 183

The Nature of Secretory Agglutinins and Aggregating Factors. I. Secretory Conglutinin-Like

Factor, Secretory Bacterial Aggregating Factors and Secretory IgA Antibody in Human Saliva and Amniotic Fluid

Eggert, F.M 192

The Nature of Secretory Agglutinins and Aggregating Factors. II. Biochemical and

Immunochemical Properties of Factors in Human Saliva and Amniotic Fluid

Eggert, F.M 203

An Investigation of the Antigens of Ascaris Lumbricoides Using a Radioimmunoassay and Sera of Naturally Infected Humans

O’Donnell, I.J. and Mitchell, G.F 213

The Effects of Diurnal Rhythms on Immune Parameters in New Hampshire Chickens

Stinson, R.; McCorkle, F.; Mashaly, M.; Taylor, R.; Martin, D., and Glick, B 220

Clonal Induction of Helper T Cells: Conversion of Specific Signals into Nonspecific Signals

Schreier, M.H. and Tees, R 227

Short Communications

Bradykinín and the Dextran Anaphylactoid Reaction in Rats

Bennett, A.J. and West, G.B 238

Correlation of Serum Theophylline Levels with Inhibition of Allergen and Histamine-Induced

Skin Tests

Fine, S.R.; Fogarty, M.; Goel, Z., and Grieco, M.H 241

IgG Antibodies to Pollen Allergens in Children with Rye-Grass Lung Sensitivity

Smart, I.J.; Hill, D.J., and Hosking, C.S 245

Production of Monoclonal Mouse IgE Antibodies with DNP Specificity by Hybrid Cell Lines

Böttcher, I.; Ulrich, M.; Hirayama, N., and Ovary, Z 248

Book Reviews 251

Contents

$\mathrm{V}$

No. 3

Original Paper

Adjuvant Effects of Amorphous Silica and of Aluminium Hydroxide on IgE and IgG, Antibody

Production in Different Inbred Mouse Strains

Mancino, D. and Ovary, Z 253

Cellular and Reaginic Immune Responses to Ragweed Antigen E in Inbred Rats

Yoo, T.J. and Kuo, C.Y 259

Effect of a Low Protein Diet on IgE Antibody Responses in Balb/c Mice

Rose, A.H. and Turner, K.J 271

Binding of Soluble Immune Complexes to Fc Receptors on Human Neutrophils - Detection by

Double-Coating Indirect Rosette Formation

An, T 278

Hereditary Angioneurotic Edema: Immunochemical ‘Activity’ without Clinical Expression

Spitzer, R.E.; Stitzel, A.E., and Urmson, J.R 286 
Subpopulations of Human T Lymphocytes. XIII. T Cell Subpopulations (T $\mu$ and Ty) in Children with Bronchial Asthma

Gupta, S.; Fikrig, S., and Good, R.A 293

Purification of Birch Pollen Allergen Extract by Gel Filtration. I. Chemical and Immunological

Characterization of the Fractions

Puttonen, E. and Pilström, L 299

Concanavalin A Inhibits the Development of Experimental Allergic Encephalomyelitis in Guinea

Pigs

Kuroda, Y.; Mori, R., and Aoki, T 308

Impaired Neutrophil Locomotion during Acute Bacterial Infections

Althaus, D.; Keller, H.U.; Hess, M.W., and Cottier, H 321

Augmentation of Guinea Pig T Lymphocyte Proliferative Response to Antigens in the Presence of Purified B Cells

Hiramine, C. and Hojo, K 329

Decreased Autologous Rosette-Forming T Lymphocytes in Alcoholic Cirrhosis. Absence of

Correlation with Other T Cell Markers and with Delayed Cutaneous Hypersensitivity

Lang, J.M.; Ruscher, H.; Hasselmann, J.P.; Grandjean, P.; Bigel, P., and Mayer, S 337

Chlorpromazine and Lidocaine Inhibit Antibody-Dependent Cell-Mediated Cytotoxicity but Not

Erythrocyte Antibody Rosette Formation

Tsokos, G.; Mandyla, H.; Xanthou, M., and Papamichail, M

Influence of Adrenergic Drugs on IgE Production

Pauwels, R.; Bazin, H.; Platteau, B., and Van Der Straeten, M

Mast Cells as a Possible Source of Haemophilus infíuenzae-lnduced Changes in Plasma and

Lung Histamine Levels

Raaijmakers, J.A.M.; Terpstra, G.K., and Kreukniet, J 352

Book Reviews 358

Announcement $\quad 360$

Erratum $\quad 360$

No. 4

Original Paper

Dog Dander Allergens. Specificity Studies Based on the Radioallergosorbent Technique

Brandt, R. and Yman, L 361 